УДК 338.45: 504: 658.5

DOI: https://doi.org/10.32840/2522-4263/2020-5-32

Vashkiv Oleksandr

PhD in Economics, Associate Professor, Associate Professor of the Department of Entrepreneurship and Trade West Ukrainian National University

Vashkiv Olesia Master's student West Ukrainian National University

Вашків 0.П. кандидат еконолічних наук, доцент, доиент кафедри підприєлництва і торгівлі Західноукраїнського національного університету

Вашків 0.0. магістрантка

Західноукраїнського національного університету

\title{
CIRCULAR ECONOMY AND ECOLOGICAL ECONOMICS AS PARADIGMS OF MODERN ENTREPRENEURSHIP DEVELOPMENT
}

\author{
ЦИРКУЛЯРНА ТА ЕКОЛОГІЧНА ЕКОНОМІКА \\ ЯК ПАРАДИГМИ РОЗВИТКУ СУЧАСНОГО ПІДПРИЕМНИЦТВА
}

\section{ANNOTATION}

The article examines theoretical foundations of the concept of a circular economy, the directions of its formation in the process of production and consumption of resources, presents the basic principles of the formation of a circular economy and ecological economics. The principles of a circular economy orientate business structures to provide appropriate conditions for redesigning their products at the system level, which, after use, will be ready for reuse or recycling. It has been substantiated that the implementation of the principles of the circular economy makes it possible to identify new sources of value creation and the possibility of obtaining additional profit for business structures: the level of consumption of materials compared to the linear production system is significantly lower; savings by increasing the maximum number of consecutive cycles and saving time for each of these cycles; diversifying the reuse of resources throughout the value chain; the use of environmentally friendly raw materials increases the efficiency of business structures, increases product durability and material productivity. All of this will ensure a high level of environmental protection and reduce the primary need of manufacturing enterprises for external resources. Consequently, the concept of a circular economy constitutes a reliable basis for rethinking business processes in entrepreneurship, contributes to the improvement of the environmental situation, and therefore, the search and implementation of appropriate business models.

Keywords: entrepreneurship, circular economy, ecological economy, linear economy, environment, closed cycle.

\section{АНОТАЦІЯ}

Сучасний розвиток українського виробничого підприємництва відбувається у вкрай неоднозначних умовах. 3 одного боку, спостерігається негативний вплив кризових явищ як на глобальному, так і на національному рівнях у всіх ссрерах суспільного життя - економічній, соціальній, культурній, політичній, екологічній, правовій, моральній та ін. 3 другого - парадигмальні зміни концептуального характеру, в основу яких закладена необхідність переходу до циркулярної та екологічної економіки і, відповідно, провадження підприємницької діяльності на нових принципах господарювання і критеріях ефективності, спроможних вибудувати таку промислову систему, що $€$ відновною і регенеративною у своїй основі та структурі, дозволяють поставити на вищий рівень питання екологічної безпеки та охорони довкілля. У статті досліджуються теоретичні засади концепції циркулярної економіки, напрями ії становлення у процесі виробництва та споживання ресурсів, представлені основні принципи формування циркулярної та екологічної економіки. На противагу лінійній економіці, принципи циркулярної економіки орієнтують підприємницькі структури на забезпечення відповідних умов для перепроектування своєї продукції на системному рівні, яка після використання буде готовою до повторного застосування чи переробки. 3 моменту проектування продукція стає частиною загального потоку замкненого циклу, а модель господарювання перебирає на себе усі ознаки відновної економіки. Идеться про включення підприємницьких структур у замкнений цикл, що дозволяє не лише переробляти відходи, але й уможливлює їх повторне відновлення, використання, модернізацію і передбачає відповідний маркетинг товарів та їх компонентів у промисловості. Обґрунтовано, що реалізація принципів циркулярної економіки дозволяє виокремити для підприємницьких структур нові джерела створення вартості та можливості отримання додаткового прибутку: рівень витрат матеріалів у порівнянні 3 лінійною виробничою системою суттєво нижчий; економія за рахунок збільшення максимальної кількості послідовних циклів та економія часу на кожен з цих циклів; диверсифікація повторного використання ресурсів протягом усього ланцюжка нарощування вартості; використання екологічно чистої сировини підвищує ефеективність підприємницьких структур, збільшує довговічність продукту і продуктивність матеріалу. Усе це забезпечить вищий рівень захисту навколишнього середовища та знизить первинну потребу виробничих підприємств у зовнішніх ресурсах. Відтак, концепція циркулярної економіки становить надійну основу для переосмислення бізнес-процесів у підприємництві, сприяє покращенню екологічної ситуації, а отже, пошуку і реалізації відповідних бізнес-моделей.

Ключові слова: підприємництво, циркулярна економіка, екологічна економіка, лінійна економіка, довкілля, замкнений цикл.

\section{АННОТАЦИЯ}

В статье исследуются теоретические основы концепции циркулярной экономики, направления ее становления в процессе производства и потребления ресурсов, представлены основные принципы формирования циркулярной и экологической экономики. Принципы циркулярной экономики ориентиру- 
ют предпринимательские структуры на обеспечение соответствующих условий для перепроектирования своей продукции на системном уровне, которая после использования будет готова к повторному применению или переработке. Обосновано, что реализация принципов циркулярной экономики позволяет выделить для предпринимательских структур новые источники создания стоимости и возможности получения дополнительной прибыли: уровень расхода материалов по сравнению с линейной производственной системой существенно ниже; экономия за счет увеличения максимального количества последовательных циклов и экономия времени на каждый из этих циклов; диверсификация повторного использования ресурсов в течение всей цепочки наращивания стоимости; использование экологически чистого сырья повышает эффективность предпринимательских структур, увеличивает долговечность продукта и производительность материала. Все это обеспечит высокий уровень защиты окружающей среды и снизит первичную потребность производственных предприятий во внешних ресурсах. Следовательно, концепция циркулярной экономики составляет надежную основу для переосмысления бизнеспроцессов в предпринимательстве, способствует улучшению экологической ситуации, а значит, поиска и реализации соответствующих бизнес-моделей.

Ключевые слова: предпринимательство, циркулярная экономика, экологическая экономика, линейная экономика, окружающая среда, замкнутый цикл.

Formulation of the problem. The development of Ukrainian entrepreneurship in the first quarter of the 21st century takes place in extremely ambiguous conditions. On the one hand, there is a negative impact of crisis phenomena both at the global and national levels in all spheres of public life: economic, social, cultural, political, environmental, legal, moral, etc. On the other, there are paradigmatic changes of a conceptual nature, based on the need for the transition to a circular economy as well as the implementation of entrepreneurial activities on new principles of management and conditions of efficiency. The implementation of these principles in entrepreneurship will allow building a modern industrial system, which is restorative and regenerative in its basis and structure, which makes it possible to raise the issues of ecological safety and environmental protection at a high level. This is what determines the relevance of the chosen research topic.

Analysis of recent research and publications. The problem of building a modern industrial system based on the principles of a circular economy is the subject of analysis by a fairly wide range of researchers. The theoretical foundations of the circular economy functioning are reflected in the works of M. Larsson [1], K. Romanova, M. Tsybka [2], O. Vashkiv, I. Boychyk [3], V. Vovk [4]. Theoretical and practical aspects of the functioning of closed-loop entrepreneurship and the corresponding business models are presented in the works of E. Guldman [5], A. Zucchella, S. Urban [6], in particular, the business model taking into account the Ukrainian realities in the study by M. Ruda, Y. Myrka [7].

Studies focused on the development of circular entrepreneurship, that take into account the opportunities and realities of the Ukrainian economy, are particularly interesting. These include the scientific works of V. Hurochkina, M. Budzyns'ka [8], I. Tymoshenko, O. Dronova [9].

Aim of the article. The purpose of the article is to substantiate the theoretical foundations of the concept of a circular economy and its formation in the process of production and consumption of resources, to determine the priority directions for introducing a circular economy in industrial entrepreneurship.

Statement of the main research material. Circular economy is an industrial system that is restorative or regenerative in design and structure; "a circular economy is an economic system where production and distribution are organized to use and re-use the same resources over and over again" [1, p. 12]. It replaces the concept of "end of life" products with the concept of its recovery and transition to the use of renewable energy sources circular. This economy eliminates the use of toxic chemicals that discourage reuse and aims to prevent waste generation through the premeditated and coordinated development or design of products, materials, systems and ultimately entrepreneurial business models.

"Today, in most countries of the world, a linear economic model prevails, in which resources are extracted, processed and turned into waste that has no further use. Therefore, the subsoil is depleted, the environment is polluted, waste is accumulated, which leads to the degradation of natural systems and environmental disasters" [2, p. 72], the problem is aggravated by limited resources while the growth of consumer demand is increasing. The latter, in turn, predetermines unsustainable overuse of resources, which ultimately leads to higher prices and instability in many markets.

As the authors of the report note "Come on! Capitalism, Short-termism, Population and the Destruction of the Planet", the existing model of economic development is fundamentally flawed. Profit maximization and saving the planet are contradictory. The new "Enlightenment" should be characterized by a significantly improved balance between man and nature, between markets and law, between private consumption and public goods, between social justice and incentives for development [12, pp. 92-99].

"The historical development of economic science led to the dominance in the 20-th century the socalled neoclassical economics - an approach that assumes simplicity of theoretical construction and ignores data about the real world that do not agree with theory. Striving for the purity and beauty of its mathematical apparatus, it neglects reality and is often criticized as the ideology of "market fundamentalism" [4]. As a result, our way of doing business has outgrown our planet. Our companies make massive contributions to the depletion of natural resources, destruction of ecosystems, climate change, depletion of water and precious arable land. We play with the future, balancing on the brink of what is permissible, believing 
that the development of technology will heal the wounds inflicted on the planet by progress. An economic model built on increasing growth with limited resources, will inevitably come to a dead end; the recent financial crisis can only be a weak boost compared to the strong economic and environmental shocks of the future. It may not be an exaggeration, but a sad reality that the very survival of many species, ecosystems and possibly humanity as such depends on the ability to move towards more advanced forms of consciousness and, accordingly, work together with new methods that can heal our relationship. with the world and eliminate the losses caused by us [10, p. 28]. "The human dominance of nature, advocated by lawyers and scientists, has produced an ongoing exploitation and destruction of nature with always more powerful technologies induced by the "industrial revolution", begun in 1769 with the creation by James Watt of the first steam engine, and still in progress. This mechanistic vision of property and sovereignty is largely responsible for the dramatic state of affairs on our planet. Now we need a resource "revolution", which means also a paradigmatic change" [6, p. 11-12].

Thus, the scientific paradigm that currently dominates the theory and practice of economic development holds several controversial underlying assumptions.

First, the economy is viewed as an isolated system in which an abstract exchange value circulates between firms and households. The physical basis of the economy is ignored - the environment, which, at best, is considered as only one of the factors of production. The decisive role of the natural environment in the supply of resources and the provision of services for the economy, in particular the absorption of waste, is largely ignored. Second, there are no boundaries to economic growth, even physical ones. It is believed that the development of technology can overcome any shortage of natural resources. Infinite growth is seen not only as possible, but also as an effective way to solve all problems. It is considered logical to extrapolate into the future the previous trends in economic growth and increase in the world's population. Third, society is viewed as a mechanical aggregate of human individuals who seek to achieve personal interests and, through the action of market forces, create a common good. The economic consideration includes neither environmental and physical limitations nor the subjective-value relations between people and different generations, as well as value relationships with the natural world, for all their importance in real human life [4].

"Industrial entrepreneurial decisions do have an impact on a company's activities, and thus on natural ecosystems and stakeholders. It is not simply a matter of knowing whether the goods and services are produced and consumed in a more or less resource-sober way; but social impact needs also to be taken into consideration. Entrepreneurs are transforming the global economy, each global project generating positive or negative interactions, inclusive or not. The breakaway from linear models applies not only to tangible resources, it also includes intangible resources and contextual assets like local territories and landscapes. The use and reuse of tangible and intangible assets are drivers of growth and progress" [6, p. 20].

That is, in contrast to linear economics, in the principle of a circular economy orientates entrepreneurial structures to provide appropriate conditions for redesigning their products at the system level, which, after use, will be ready for reuse or processing. From the moment of design, products become part of the general flow of a closed cycle, and the economic model takes on all the signs of a recovery economy. "All stages of the value chain are getting concerned, from design to manufacturing, to distribution, to use, to valorization of materials and substances, to the creation of new business models. The Internet of "Things" is pushing industry into a new digital age, the "4.0," where flows of goods are better connected and where the use of resources and finished products can be identified and optimized" $[6$, p. 22].

Today, one of the main indicators of the development of any country is its economic growth. Focusing on economic growth and neglecting environmental issues and depletion of natural resources puts humanity on the path of ecological collapse. At the same time, it is sacrificing support for the achieved level of wellbeing, and even survival. The development of policies and institutions for a stable economy will require a revision of the question of the goals of reorienting the economy towards building closed cycles of reusing material resources. "The circular supplies business model is about phasing out scarce resources by using fully renewable, recyclable or biodegradable resources" [5, p. 16].

The principles of functioning of a circular economy arise from $H$. Daly's concept of an "empty" and "full" world [11].

Neoclassical (linear) economics was formed in the conditions of an "empty world", where there was no obvious conflict between the economy and the ecosphere, "the population was small and the bounty of natural resources on this earth seemed endless" [12, p. 9]. However, due to exponential economic growth since the World War II, humanity now lives in a "complete" world, but it still behaves as if it is empty, with enough space and resources to the distant future [11]. Today, the aggregate anthropogenic load on the ecosystem reaches maximum, and in some cases exceeds the limits of nature at the local, regional and global levels [11]. Despite this, views on the need for further economic of growth, putting humanity on the path of ecological collapse dominates in political and economic circles. To reverse this 
pernicious trajectory, we must move to a stable economy focused on quality development, as opposed to quantitative growth and the coherence of the economy and the global ecosphere [11].

The solution to these problems lies in the transition to a circular economy. We are talking about the inclusion of entrepreneurial structures in a closed cycle, which allows not only to recycle waste, but also to re-recover, use, modernization, and involves the appropriate marketing of goods and their components in industry.

Today these issues are being discussed more and more actively in the countries of the European Union. In particular, the concept of a circular economy is being introduced, according to which the production and consumption systems require fundamental changes and transformations in order to be permanent and to achieve the goal of life within the capabilities of our planet by 2050. As part of its 2020 strategy for the EU, the European Commission has decided to move towards a rehabilitative economic system that will stimulate significant and long-term increases in resource productivity. In the field of entrepreneurship, in accordance with the decisions made, it is planned to build new business models, which are based on the principles of environmental design, repair, restoration, reuse, product exchange and comprehensive waste prevention. "In a circular economy, waste is minimized at all stages of production, and innovation is applied throughout the value chain, in contrast to the dominant practice of finding solutions at the final stages of the product life cycle" [9, p. 122].

The first steps towards building a circular economy are being made in Ukraine. In particular, since 2013, Ukraine, among the six countries of the EU's Eastern Partnership, has been implementing the "EaP GREEN" program. Its task lies in the transition to a "green" recovery economy. Funding for this program is provided by the EU.

One of the main components of the "EaP GREEN" program is the "Resource Efficient Cleaner Production Demonstration Project". According to this project, principles and approaches for the efficient and economical use of resources are spread among small and mediumsized businesses [2, p. 72].

Such changes are only an initial stage in the direction of a circular economy, but their prospects are undeniable. It is on their basis that a response to a number of fundamental challenges of our time is laid. Thus, a reductive circular model of the economy separates economic growth and harmful dependence on primary resources. The economic cycle is considered as a continuous material flow, in which nothing is lost. "A circular economy is an industrial system that is restorative or regenerative by intention and design. It replaces the end-oflife concept with restoration, shifts towards the use of renewable energy, eliminates the use of toxic chemicals and aims for the elimination of waste through the superior design of materials, products, systems and business models. Nothing that is made in a circular economy becomes waste, moving away from our current linear "takemake-dispose" economy. The circular economy's potential for innovation, job creation and economic development is huge: estimates indicate a trilliondollar opportunity" [13].

The circular economy is based on a few simple principles and in the field of entrepreneurship it provides:

1) focus on "design without waste". There is no waste, as products are designed and optimized so that they can be disassembled and reused at end of life. This combination of component and product life-cycles is a defining characteristic of the circular economy, eliminating the need to recycle waste. The circular model introduces a clear differentiation between consumable and durable product components;

2) cycling implies a clear distinction between consumables and durable components that are part of the finished product. Consumer goods in a circular economy, unlike current ones, are largely composed of biological components or "nutrients" that are not toxic and, moreover, may have beneficial properties. They can be safely returned directly to the biosphere through consistent use. On the contrary, durable goods made from technical elements containing metals and plastics and are unsuitable for biosphere disposal, from the moment of design, should provide for their reuse. "In a traditional economy, manufacturers often do not distinguish between them. But in the new economy, the goal of consumables is to use non-toxic and clean components so that they eventually return to the biosphere, where they can have an additional effect. The purpose of durable components (such as metals and most plastics) is to reuse or upgrade for other manufacturing applications through as many cycles as possible. Consequently, in a circular economy, products are designed in the specific way to provide cycles of disassembly, sorting and reuse, reducing or completely eliminating waste" [7, p. 110];

3) the energy required for the functioning of the cycle, by its nature, must be renewable, thereby reducing dependence on resources and increasing the stability of the system.

In regards to the technical elements of the product, the circular economy largely replaces the concept of "consumer" with the concept of "user". Therefore, product performance should be the basis for agreements between companies and their potential consumer customers. Unlike today's buy-and-consume economy, durable goods are rented, or shared wherever possible. In any case, incentives and conditions are created, enshrined in agreements that provide for the return of the product, and then its reuse or components of products and materials at the end of the main use period. The World Economic Forum sees the main directions "to accelerate the circular economy, by 
embracing the need to recover, recycle, repurpose, refurbish, repair, refuse, rethink, reduce, reuse and remanufacture waste" [13].

The indicated principles of a circular economy make it possible to identify four sources of value creation and opportunities for additional profit for business structures.

Firstly, the level of material consumption is significantly lower compared to a linear production system. Therefore, the denser the product cycle (the number of changes that the product undergoes before it is recovered and reused) and the faster it returns to use, the higher the potential savings in materials, labor, energy and capital allocated to the product. Secondly, savings by increasing the maximum number of consecutive cycles, whether it is reuse, secondary production or recycling, and the time for each of these cycles. Thirdly, diversification of reuse throughout the value chain - cascading product use, their elements and materials in the entrepreneurial structures of various industries. Fourthly, the use of environmentally friendly raw materials increases the efficiency of entrepreneurial structures and its redistribution while maintaining quality, especially in technical materials, which, in turn, increases the durability of the product, and hence the productivity of the material.

The transition to a model of economic development, based on the principles of a circular economy, will mostly affect industrial entrepreneurship. The changes will affect both the choice of raw materials, methods and technology for manufacturing products, and the use of byproducts of some industries as a full-fledged raw material. This will avoid losses in the cost of materials and products, reduce the level of scarcity of resources, prevent price increases and waste accumulation, reduce the level of environmental degradation, create favorable conditions for the development of innovations and growth in the number of jobs, increase the level and safety of products and services [3, p. 17].

"We all know that the world is in crisis. Science tells us that almost half of the top soils on earth have been depleted in the last 150 years1; nearly $90 \%$ of fish stocks are either overfished or fully fished. Climate stability is in real danger; and the earth is now in the sixth mass extinction period in history" [12, p. 1]. These words of warning begin the report released by the Club of Rome in 2017 on the occasion of the anniversary of the founding of the organization and reflect the consolidated position of its members.

"The human ability to do has vastly outstripped the ability to understand. As a result, civilization is faced with a perfect storm of problems, driven by overpopulation, overconsumption by the rich, the use of environmentally malign technologies and gross inequalities. The rapidly deteriorating biophysical situation is barely recognized by a global society infected by the irrational belief that physical economies can grow forever" [12, p. 1].
Neoclassical economics is relevant in isolation from the natural biophysical limitations of the Earth, and classical theories have been criticized for their inefficiency in boundary conditions. Therefore, new paradigms are needed, such as, ecological economics, which is designed to change not only world-view principles in relation to the environment, but also the main principles in organizing and carrying out business activities. As a synthesizing science, it brings together the approaches and achievements of various scientific schools and disciplines and offers an integrated view of economic activity in the context of its relationship with the natural environment and human communities. Ecological economics studies the economic system not separately from the natural system, but as the only ecological and economic complex. In ecological economics, the processes of production and consumption of products affect natural systems to such an extent that they do not exceed the thresholds for their self-reproduction. This scientific trend synthesizes the economic, environmental and social aspects of human economic activity. Its scientific paradigm is based on the following fundamental principles:

1. The economy is an open subsystem of the planet's ecosystem and functions within the natural - physical and biological - limiting factors, or planetary limitations.

2. Connection between economics and entropy and the concept of entropic resource flow. Entropy in economics is a measure of the qualitative difference between useful inputs and unnecessary waste outputs. No economy can exist without an entropic resource flow.

3. The concept of "scale" of the economy in the ecosystem. The "scale" of the economy is understood as its physical volume, or the relative size of the human presence in the ecosystem. Since the size of the planet remains unchanged with the growth of the economy, the scale of the economy to the ecosystem inevitably increases over time.

4. The concept of "natural capital" as an economic category. Natural capital is a fund that produces a flow of natural resources and services. It should be understood as oil deposits, forest regenerating timber flow, fish population in the ocean, regenerating fish flow and freshwater basin providing water supply. Natural capital also provides people with many services that support their economic activities, such as waste absorption, self-purification of air and water bodies, photosynthesis and oxygen regeneration, maintenance of natural soil fertility, recreational services, etc. [4].

The modern world is moving from an era in which human capital was the limiting factor to an era in which the remaining natural capital becomes the limiting factor. The fish catch is currently limited by the number that remains in the oceans, and not by the number of fishing vessels. Wood production is limited by the available forests, not by the number of sawmills. The consumption 
of oil and coal is limited by the ability of the atmosphere to absorb carbon dioxide emissions from combustion. Finally, agricultural production is limited by soil degradation and depletion of water basins for irrigation, rather than a shortage of chemicals, tractors and combines [11]. However, the economic logic remains unchanged under the new global deficit pattern.

5.Theparadigm of "co-evolutionarydevelopment" of people and nature. The co-evolution of human systems, such as values, knowledge, technology and material culture, and natural systems with their constant mutual influence and adaptation is taking place. The co-evolution paradigm has two important implications in the context of the idea of sustainable human development. Firstly, coevolution does not necessarily mean progress that will ensure lifelong survival for humans, as the ultimate link in evolution. Long-term domination and success of people is not a guarantee of eternal survival. Secondly, the co-evolutionary essence of the relationship between people and nature leaves an inevitable minimum of unpredictability, since both natural systems and human civilization are complex dynamic systems.

Within the ecological economy, there are three independent political economic goals. These are efficient siting, equitable distribution and environmentally sustainable scale, requiring three different policy instruments.

1. Efficient allocation of resources within the economy is a microeconomic problem that the market solves.

2. Equitable distribution of the economic product is carried out through the policy of redistribution of income and social programs.

3. Environmentally sustainable scale is ensured by its regulatory definition by the national state or the international community [4].

An example of the realization of political goals of scale, distribution and placement and the relationship between them is the issuance and trade of permissive licenses (quotas) for pollution. This is how the modern $\mathrm{CO} 2$ trading system in the European Union was built.

Another example is the policy of eco-labor tax reform, which is key in addressing job creation and environmental protection. This reform is based on the understanding that the current tax systems are unbalanced, therefore, energy and natural resources are too cheap (which encourages inefficiency and waste), and the cost of labor due to its excessive taxation is too high. Thus, there are barriers to hiring new workers or formal remuneration for their work.

Obviously, this results in overuse of natural resources and inadequate job creation, as well as shadow hiring. Therefore, the idea of the reform in taxing more on the "bad" (resource consumption and pollution) and less on the "good" (jobs and incomes) can become the basis for a strategy to increase the competitiveness of the economy in the context of globalization.
Conclusions. The modern development of the economy, especially in the field of industrial entrepreneurship and its infrastructure, requires a transition to the principles of a circular economy and ecological economics. This, in turn, is directly related to the need of forming fundamentally new business models focused on reducing the amount of resources used, the introduction of their reuse in the process of a closed production cycle, restoration, redesign and recycling. This ensures a high level of environmental protection and reduces the primary need of manufacturing enterprises for external resources. Therefore, the concept of a circular economy should become a reliable basis for rethinking business processes in entrepreneurship, contribute to improving the environmental situation, and thus, the search for and implementation of appropriate business models, which is the prospect of further research on the declared topic.

\section{REFERENCES:}

1. Larsson M. Circular Business Models. Developing a Sustainable Future. Cham, 2018. 303 p. DOI: 10.1007/978-3319-71791-3.

2. Romanova K., Tsybka M. (2017) Do ekonomiky zamknenoho tsyklu [To a closed-loop economy]. Ecology of the enterprise, vol. 11, pp. 72-73.

3. Vashkiv O.P., Boychyk I.M. (2018) Realizatsiya pryntsypiv tsyklovoyi ekonomiky u pidpryyemnytstvi [Implementation of the principles of cyclical economy in entrepreneurship]. Proceedings of the Status and prospects of development of financial and economic potential of modern enterprises : materials of the International scientificpractical conference (Ukraine, Dnipro, 23 August, 2018). Dnipro : NO "Perspektyva", pp. 14-17. DOI: 10.6084/m9. figshare.7038515.

4. Vovk V. (2019) Vid "kovboys'koyi" ekonomiky do ekonomiky "kosmichnoho korablya" [From the "cowboy" economy to the "spaceship" economy]. Ukrainian Week, vol. 34. Available at: https://tyzhden.ua/Economics/234254\#.XXdvudnKL5s.facebook (accessed 17 September, 2020).

5. Guldman E. Best practice examples of circular business models. Copenhagen : The Danish Environmental Protection Agency, 2016. 57 p. DOI: 10.13140/RG.2.2.33980.95360.

6. Zucchella A., Urban S. Circular Entrepreneurship: Creating Responsible Enterprise. Cham : Springer International Publishing, 2019. 234 p. DOI: 10.1007/978-3-030-18999-0.

7. Ruda M.V., Myrka YA.V. (2020) Tsyrkulyarni biznes-modeli $v$ Ukrayini [Circular business-models in Ukraine]. Management and entrepreneurship in Ukraine: stages of formation and problems of development, vol. 1, pp. 107-121.

8. Hurochkina V., Budzyns'ka M. (2020) Tsyrkulyarna ekonomika: ukrayins'ki realiyi ta mozhlyvosti dlya promyslovykh pidpryyemstv [Circular economy: Ukrainian realities and opportunities for industrial enterprises]. Economic Bulletin. Series: finance, accounting, taxation, vol. 5, pp. 52-64. DOI: 10.33244/2617-5932.5.2020.52-64

9. Tymoshenko I.P., Dronova O.L. (2018) Tsyrkulyarna ekonomika dlya umov Ukrayiny [Circular economy for the conditions of Ukraine]. Formation of market relations in Ukraine, vol. 9, pp. 120-127. DOI: 10.5281/zenodo.1485209. 
10. Laloux F. (2017) Kompaniyi maybutn'oho [Reinventing organi-zations]. Kharkiv : Klub simeynoho dozvillya. (in Ukrainian)

11. Daly H. Economics for a Full World. Scientific American. 2005 №293, pp.100-107.DOI:10.1038/scientificamerican0905-100.

12. Von Weizsäecker E., Wijkman A. Come On! Capitalism, Short-termism, Population and the Destruction of the Planet A Report to the Club of Rome. Springer, 2017. 232 p. DOI: 10.1007/978-1-4939-7419-1.

13. Charlton E. 5 ways to \#BeatAirPollution. World Economic Forum. 05.06.2020. Available at: https://www.weforum.org/ agenda/2019/06/5-ways-to-beatairpollution (accessed 10 October, 2020).

\section{БІБЛІОГРАФІЧНИЙ СПИСОК:}

1. Larsson M. Circular Business Models. Developing a Sustainable Future. Cham, 2018. 303 p. DOI: 10.1007/978-3319-71791-3.

2. Романова К., Цибка М. До економіки замкненого циклу. Екологія підприємства. 2017. № 11. С. 72-73.

3. Вашків О.П., Бойчик І.М. Реалізація принципів циклової економіки у підприємництві. Стан та перспективи розвитку фрінансово-економічного потенціалу сучасних підприємств : матеріали Міжнародної науково-практичної конфреренції (Дніпро, 23.08.2018р.). Дніпро : НО «Перспектива», 2018. C. 14-17. DOI: 10.6084/m9.figshare.7038515.

4. Вовк В. Від «ковбойської» економіки до економіки «космічного корабля». Український тиждень. 2019. № 34.
URL: https://tyzhden.ua/Economics/234254\#.XXdvudnKL5s. facebook (дата звернення: 17.09.2020).

5. Guldman E. Best practice examples of circular business models. Copenhagen : The Danish Environmental Protection Agency, 2016. 57 p. DOI: 10.13140/RG.2.2.33980.95360.

6. Zucchella A., Urban S. Circular Entrepreneurship: Creating Responsible Enterprise. Cham : Springer International Publishing, 2019. 234 p. DOI: 10.1007/978-3-030-18999-0.

7. Руда М.В., Мирка Я.В. Циркулярні бізнес-моделі в Україні. Менеджмент та підприємництво в Україні: етапи становлення та проблеми розвитку. 2020. Вип. 2. № 1. С. 107-121.

8. Гурочкіна В., Будзинська М. Циркулярна економіка: українські реалії та можливості для промислових підприємств. Економічний вісник. Серія: фрінанси, облік, оподаткування. 2020. № 5. C. 52-64. DOI: 10.33244/2617-5932.5.2020.52-64.

9. Тимошенко І.П., Дронова О.Л. Циркулярна економіка для умов України. Формування ринкових відносин в Україні. 2018. № 9. C. 120-127. DOI: 10.5281/zenodo.1485209.

10. Лалу Ф. Компанії майбутнього / пер. з англ. Р. Ключка. Харків : Клуб сімейного дозвілля, 2017. 544 с.

11. Daly H. Economics for a Full World. Scientific American. 2005. № 293. P. 100-107. DOI: 10.1038/scientificamerican0905-100.

12. Von Weizsäecker E., Wijkman A. Come On! Capitalism, Short-termism, Population and the Destruction of the Planet A Report to the Club of Rome. Springer, 2017. 232 p. DOI: 10.1007/978-1-4939-7419-1.

13. CharltonE.5waysto\#BeatAirPollution. WorldEconomicForum. 05.06.2020. URL: https://www.weforum.org/agenda/2019/ 06/5-ways-to-beatairpollution (дата звернення: 10.10.2020). 